\title{
Hematological shift in goat kids naturally devoid of prion protein
}

\author{
Malin R. Reiten, Maren K. Bakkebø, Hege Brun-Hansen, Anna M. Lewandowska-Sabat, \\ Ingrid Olsaker, Michael A. Tranulis, Arild Espenes* and Preben Boysen
}

Faculty of Veterinary Medicine and Biosciences, Norwegian University of Life Sciences, Oslo, Norway

\section{OPEN ACCESS}

Edited by:

P. Hemachandra Reddy,

Texas Tech University, USA

Reviewed by:

Ritu Chakravarti,

Cleveland Clinic, USA Yasuhito Ishigaki,

Kanazawa Medical University, Japan

*Correspondence:

Arild Espenes,

Department of Basic Sciences and

Aquatic Medicine, Faculty of Veterinary Medicine and Biosciences, Norwegian University of Life Sciences, Ullevålsveien 72, 0454 Oslo, Norway arild.espenes@nmbu.no

Specialty section:

This article was submitted to

Cellular Biochemistry,

a section of the journa

Frontiers in Cell and Developmental

Biology

Received: 20 April 2015

Accepted: 19 June 2015

Published: 08 July 2015

Citation:

Reiten MR, Bakkebø MK Brun-Hansen H, Lewandowska-Sabat AM, Olsaker I, Tranulis MA, Espenes A and Boysen P (2015) Hematological shift in goat kids naturally devoid of prion protein.

Front. Cell Dev. Biol. 3:44. doi: 10.3389/fcell.2015.00044
The physiological role of the cellular prion protein $\left(\mathrm{PrP}^{\mathrm{C}}\right)$ is incompletely understood. The expression of $\mathrm{PrPC}^{\mathrm{C}}$ in hematopoietic stem cells and immune cells suggests a role in the development of these cells, and in $\operatorname{PrP}^{\mathrm{C}}$ knockout animals altered immune cell proliferation and phagocytic function have been observed. Recently, a spontaneous nonsense mutation at codon 32 in the PRNP gene in goats of the Norwegian Dairy breed was discovered, rendering homozygous animals devoid of $\mathrm{PrP}^{\mathrm{C}}$. Here we report hematological and immunological analyses of homozygous goat kids lacking $\mathrm{PrP}^{\mathrm{C}}$ (PRNPTer/Ter) compared to heterozygous ( $P R N P^{+/ \text {Ter }}$ ) and normal $\left(P R N P^{+/+}\right)$kids. Levels of cell surface PrPC and PRNP mRNA in peripheral blood mononuclear cells (PBMCs) correlated well and were very low in $P R N P^{T e r / T e r}$, intermediate in $P R N P^{+/ T e r}$ and high in $P R N P^{+/+}$kids. The PRNPTer/Ter animals had a shift in blood cell composition with an elevated number of red blood cells (RBCs) and a tendency toward a smaller mean RBC volume $(P=0.08)$ and an increased number of neutrophils $(P=0.068)$, all values within the reference ranges. Morphological investigations of blood smears and bone marrow imprints did not reveal irregularities. Studies of relative composition of PBMCs, phagocytic ability of monocytes and T-cell proliferation revealed no significant differences between the genotypes. Our data suggest that $\mathrm{PrPC}^{\mathrm{C}}$ has a role in bone marrow physiology and warrant further studies of $\mathrm{PrPC}^{\mathrm{C}}$ in erythroid and immune cell progenitors as well as differentiated effector cells also under stressful conditions. Altogether, this genetically unmanipulated $\mathrm{PrP}^{\mathrm{C}}$-free animal model represents a unique opportunity to unveil the enigmatic physiology and function of $\mathrm{PrP}^{\mathrm{C}}$.

\section{Keywords: cellular prion protein, $\mathrm{PrP} \mathrm{C}^{\mathrm{C}}$, hematology, hematopoiesis, phagocytosis, T-cell proliferation}

\section{Introduction}

The cellular prion protein $\left(\mathrm{PrP}^{\mathrm{C}}\right)$ was first described as the substrate for $\operatorname{PrP}$ scrapie $\left(\mathrm{PrP}^{\mathrm{Sc}}\right)$ (Prusiner, 1982; Brandner et al., 1996a,b), a misfolded and aggregation-prone form of the protein detected in brain tissue of animals diagnosed with transmissible spongiform encephalopathies, now often called prion diseases. These are fatal neurodegenerative diseases occurring naturally in humans and ruminants and include Creutzfeldt-Jakob disease, bovine spongiform encephalopathy, scrapie, and chronic wasting disease. The process of template-directed self-replication of $\mathrm{PrP}^{\mathrm{Sc}}$ constitutes the core of the "protein only" hypothesis (Prusiner et al., 1998), stating that the prion agent consists solely of misfolded $\mathrm{PrP}^{\mathrm{C}}$ conformers, and in accordance with this, $\mathrm{PrP}^{\mathrm{C}}$ knock-out (KO) mice do not replicate prions, nor do they develop prion disease (Bueler et al., 1992). 
$\mathrm{PrP}^{\mathrm{C}}$ is a highly conserved GPI-anchored protein (Steele et al., 2007) expressed abundantly in the central nervous system (CNS) (Kretzschmar et al., 1986), but also at lower levels in many other cells like hematopoietic (Zhang et al., 2006) and embryonic stem cells (Miranda et al., 2011), immune cells (Isaacs et al., 2006) and various epithelial cell types (Horiuchi et al., 1995; Ford et al., 2002), suggesting that $\operatorname{PrP}^{C}$ might have important functions within these cell types (Bendheim et al., 1992). In view of this, it was puzzling that $\mathrm{PrP}^{\mathrm{C}} \mathrm{KO}$ mice developed normally without overt phenotypic abnormalities (Bueler et al., 1992; Manson et al., 1994). Subsequent analyses have; however, revealed various phenotypes such as altered circadian rhythms (Tobler et al., 1996), behavior abnormalities (Roesler et al., 1999; Massimino et al., 2013), increased susceptibility to oxidative stress (Wong et al., 2001), and increased excitability of neurons (Khosravani et al., 2008).

In bone marrow, $\mathrm{PrP}^{\mathrm{C}}$ is expressed in long-term hematopoietic stem cells (Dodelet and Cashman, 1998; Zhang et al., 2006) and may contribute to maintenance of stem cell properties, since bone marrow stem cells derived from $\mathrm{PrPC}^{\mathrm{C}}$ KO mice, contrary to similar cells from wild-type mice, fail to repopulate the bone marrow of irradiated recipient mice, especially after serial transplantations (Zhang et al., 2006). Interestingly, the $\mathrm{PrP}^{\mathrm{C}}$ expression in immune cells is regulated according to their lineage fate. The observation that $\mathrm{PrP}^{\mathrm{C}}$ expression is maintained at a high level in mononuclear cell precursors and downregulated in granulocytic and erythroid cells during their maturation in the bone marrow suggests that $\mathrm{PrP}^{\mathrm{C}}$ plays a role in the dynamic development of these cells (Dodelet and Cashman, 1998). $\operatorname{PrP}^{\mathrm{C}}$ is upregulated in activated T lymphocytes (Mabbott et al., 1997) and neutrophils (Mariante et al., 2012) and has been suggested to act as a signaling molecule in the activation of immune cells (Mattei et al., 2004; Krebs et al., 2006), but the definite role of $\mathrm{PrP}^{\mathrm{C}}$ in these processes remains unclear.

Whether $\mathrm{PrP}^{\mathrm{C}}$ modulates macrophage functions, in particular phagocytic capacity is controversial. Peritoneal macrophages devoid of $\mathrm{PrP}^{\mathrm{C}}$ displayed increased phagocytosis toward apoptotic cells in comparison with wild-type macrophages (De Almeida et al., 2005), suggesting that $\mathrm{PrP}^{\mathrm{C}}$ acts as a negative modulator of phagocytosis. Similar results were recently reported in a study using primary cell culture of bone marrow-derived macrophages from $\mathrm{ZrchI}$ type $\mathrm{PrP}^{\mathrm{C}} \mathrm{KO}$ mice in comparison with similar cells derived from C57BL/6 mice (Wang et al., 2014), where the $\mathrm{PrP}^{\mathrm{C}}$-depleted macrophages displayed increased phagocytic capacity toward fluorescently labeled E. coli, enhanced phagosome maturation and cytokine expression. Uraki and coworkers; however, reached the opposite conclusion when using immortalized bone marrow-derived macrophages from ZrchI type $\mathrm{PrP}^{\mathrm{C}} \mathrm{KO}$ mice, observing that loss of $\mathrm{PrP}^{\mathrm{C}}$ reduced phagocytic capacity toward fluorescent latex beads (Uraki et al., 2010).

Likewise, the proliferative response of $\mathrm{T}$ cells in vitro upon cytokine stimulation has been studied in cells from transgenic mice and cattle with and without $\operatorname{PrP}^{\mathrm{C}}$. Murine studies demonstrated a reduced proliferative response (Mabbott et al., 1997) and altered cytokine profile (Bainbridge and Walker, 2005) in Concanavalin A (Con A)-stimulated T cells from $\mathrm{PrP}^{\mathrm{C}} \mathrm{KO}$ mice indicating a role for $\mathrm{PrP}^{\mathrm{C}}$ in $\mathrm{T}$-cell pathways leading to proliferation. Data from transgenic $\mathrm{PrP}^{\mathrm{C}} \mathrm{KO}$ cattle (Richt et al., 2007) revealed no differences in the proliferative response of $\mathrm{T}$ cells when stimulated with anti-CD3 antibody, Con A and phytohemagglutinin. A further clarification of $\mathrm{PrP}^{\mathrm{C}}$ 's roles in stem cell and immune cell maturation and function is desirable and will be helpful in understanding $\operatorname{PrP}^{C}$ 's functions in general.

Recently, a unique line of otherwise healthy Norwegian dairy goats carrying a nonsense mutation at codon 32 (premature termination codon, Ter) in the PRNP reading frame was discovered (Benestad et al., 2012). The mutation results in an early termination of $\mathrm{PrP}^{\mathrm{C}}$ synthesis and consequently animals homozygous for this mutation are devoid of $\operatorname{PrP}^{\mathrm{C}}$. This is, to our knowledge, the first species identified that is naturally devoid of $\mathrm{PrP}^{\mathrm{C}}$. These animals are genetically unmanipulated and therefore represent a unique spontaneous animal model to complement the transgenic models available for studies of $\mathrm{PrP}^{\mathrm{C}}$ functions.

Here, we report results of hematological and immunological analyses of goat kids without $\mathrm{PrP}^{\mathrm{C}}$ expression $\left(P R N P^{\mathrm{Ter}} / \mathrm{Ter}\right)$ compared to heterozygotes $\left(P R N P^{+/ T e r}\right)$ and normal $\left(P R N P^{+/+}\right)$ goats.

\section{Methods}

\section{Animals and Sampling}

The animals included in this study were of the Norwegian Dairy Goat Breed obtained from a research herd of around 100 animals at the Norwegian University of Life Sciences. Based on daily monitoring and enhanced health surveillance through a national goat health monitoring service, the health status of this flock is considered to be very good. Scrapie outbreaks have never occurred and there have been no cases of caprine arthritis encephalitis, Johne's disease or caseous lymphadenitis during the last 5 years (i.e., diseases subject to surveillance and control program in Norway) (Nagel-Alne et al., 2014). The entire flock was previously analyzed for PRNP genotypes (Benestad et al., 2012) and through selective breeding goat kids with the desired $P R N P^{\mathrm{Ter} / \mathrm{Ter}}$ genotypes were retrieved. No animals died of disease during the observation time and all $P R N P^{\text {Ter/Ter }}$ offspring developed normally during their first 6 months with no signs of behavioral or health problems. The Norwegian Animal Research Authority approved the protocol with reference to the Norwegian regulation on animal experimentation (FOR-199601-15-23, § 2) which is based upon the European Convention for the Protection of Vertebrate Animals used for Experimental and Other Scientific Purposes.

Blood was drawn from the jugular vein into heparinized tubes and tubes without anticoagulant from age matched goat kids at 3-4 weeks of age. For hematological and clinical chemistry analyses, goat kids carrying the genotypes $\operatorname{PRN} P^{\mathrm{Ter} / \mathrm{Ter}}(n=8)$, $P R N P^{+/ T e r}(n=16)$, and $P R N P^{+/+}(n=24)$ were included.

Hematological analyses were performed with an Advia ${ }^{\circledR}$ 2120 Hematology System using Advia 2120 MultiSpecies System Software and clinical chemistry analyses were performed with Advia 1800 Chemistry System (both from Siemens AG Healthcare Sector). 
Peripheral blood mononuclear cells (PBMCs) were isolated from PRNP $P^{\text {Ter/Ter }}(n=8)$ and $P R N P^{+/+}(n=8)$ goat kids by gradient centrifugation (Lymphoprep, Axis-Shield) at $1760 \times$ g. Red blood cells (RBC) were lysed by brief exposure to sterile water prior to counting and trypan blue viability assessment using a Countess Automated Cell Counter (Life Technologies).

\section{Morphology}

For morphological studies, two age-matched male kids, one $P R N P^{\text {Ter/Ter }}$ and one $P R N P^{+/+}$, were necropsied at 3 months of age. Macroscopic examinations were performed routinely. Fresh bone marrow imprints and smears were made and evaluated after staining with May Grünewald Giemsa. Histological slides were prepared from formalin fixed and paraffin-embedded tissues and stained with hematoxylin and eosin (HE) prior to examination by light microscopy.

\section{Real-time RT-PCR Analysis}

Total RNA was isolated from PBMCs using the Qiagen RNeasy mini plus kit (Qiagen) following the manufacturer's instructions. RNA concentration and purity was analyzed using NanoDrop1000 Spectrophotometer (Thermo Fisher Scientific), and quality was assessed using RNA Nano Chips on an Agilent 2100 Bioanalyzer (both from Agilent Technologies). RNA was stored at $-80^{\circ} \mathrm{C}$. cDNA was synthesized using the SuperScript III Reverse Transcriptase, RNase Out, dNTP mix and Random Primers (all from Invitrogen, Life Technologies) at the following conditions: $5 \mathrm{~min}$ at $65^{\circ} \mathrm{C},>1 \mathrm{~min}$ on ice, $5 \mathrm{~min}$ at $25^{\circ} \mathrm{C}, 1 \mathrm{~h}$ at $50^{\circ} \mathrm{C}$, and $15 \mathrm{~min}$ at $70^{\circ} \mathrm{C}$.

Quantitative-PCR was conducted with LightCycler 480 Sybr Green I Master mix (Roche), with PRNP as target gene (F: GTG GCT ACA TGC TGG GAA GT; R: AGC CTG GGA TTC TCT CTG GT) and glyceraldehyde 3-phosphate dehydrogenase $(G A P D H)$ as reference gene (F: GGT TGT CTC CTG CGA CTT CA; R: TGG AAA TGT GTG GAG GTC GG). cDNA corresponding to $1 \mathrm{ng}$ RNA was used per reaction. The samples had a total volume of $20 \mu \mathrm{l}$, and were run on a LightCycler 480 System (Roche). Conditions: $5 \mathrm{~min}$ at $95^{\circ} \mathrm{C} ; 40$ cycles of $10 \mathrm{~s}$ at $95^{\circ} \mathrm{C}, 10 \mathrm{~s}$ at $60^{\circ} \mathrm{C}$, and $10 \mathrm{~s}$ at $72^{\circ} \mathrm{C}$; and melting curve with $5 \mathrm{~s}$ at $95^{\circ} \mathrm{C}, 1 \mathrm{~min}$ at 65 and $97^{\circ} \mathrm{C}$. Relative expression levels were calculated using an externally run standard curve for the PBMCs generated from one $P R N P^{+/+}$animal, run in duplicates, with one randomly selected $P R N P^{+/+}$as positive control (in-run).

\section{Flow Cytometry for Cell Surface PrP and Immune Cell Markers}

Immunophenotyping in flow cytometry was performed as previously described (Olsen et al., 2013). Briefly, isolated PBMCs, or whole blood if indicated, were incubated with Fixable Yellow Dead Cell Stain Kit (Life Technologies, Thermo Fisher Scientific Inc.) followed by primary monoclonal antibodies (mAbs), brief incubation with $30 \%$ normal goat serum to block Fc-receptors, and finally fluorescence-labeled goat-antimouse secondary antibodies (see Supplementary Table 1). To detect the intracellular CD3 epitope, surface-labeled cells were permeabilized with Intracellular Fixation and Permeabilization Buffer Set (eBioscience, Affymetrix Inc.) according to the manufacturer's instructions. Labeled cells were analyzed in a Gallios flow cytometer and data were processed using Kaluza 1.2 software (both Beckman Coulter, Inc.). Cell gates were designed to select for single and viable mononuclear cells.

\section{Lymphocyte Proliferation Test}

PBMCs were incubated in a flat-bottom 96 well plate for $72 \mathrm{~h}$ in complete medium with a density of $2 \times 10^{5}$ cells per well. Cells were stimulated with Concanavalin A (ConA; Sigma-Aldrich) $(200 \mu \mathrm{g} / \mathrm{ml})$, recombinant ovine interleukin (IL)$2(10,000 \mathrm{U} / \mathrm{ml})$ (Connelley et al., 2011) or recombinant human (rh)IL-15 (Affymetrix/eBioscience) $(25,000 \mathrm{U} / \mathrm{ml})$. Unstimulated cells were used as controls. Each treatment was run in three to six parallels. Proliferation was measured as $24 \mathrm{~h}$ uptake of $3 \mathrm{H}$-thymidine (Perkin-Elmer, Waltham, USA) as previously described (Storset et al., 2001) in counts per minute (CPM). Parallels outside $\pm 50 \%$ of the median were excluded, and net proliferation (net CPM) was calculated as mean of stimulated cells minus mean of unstimulated cells.

\section{Isolation of Monocytes and Phagocytosis Assays}

$\mathrm{CD}_{14}{ }^{+}$monocytes were positively selected from isolated PBMCs by anti-human CD14 MACS MicroBeads (Miltenyi Biotec $\mathrm{GmbH}$, Bergisch Gladbach, Germany) using $10 \mu \mathrm{l}$ beads per $10^{7}$ cells. The purity was consistently measured between 90 and $95 \%$ by flow cytometry using anti-CD14 mAbs (TUK4; IgG2a; $\mathrm{AbD}$ Serotec). $\mathrm{CD} 14^{+}$monocytes were seeded in a 96 well nonadherent plate (Corning Costar Ultra-Low Attachment multiwell plates) in complete medium [RPMI $+10 \%$ fetal calf serum (FCS) $+1 \%$ Penicillin/Streptomycin; Gibco] at $2 \times 10^{5}$ cells per well and incubated for $24 \mathrm{~h}$ at $37^{\circ} \mathrm{C}$ and $5 \% \mathrm{CO}_{2}$ in the presence of $5000 \mathrm{U} / \mathrm{ml}$ recombinant bovine granulocyte macrophage colony stimulating factor (rbGM-CSF) that had been expressed in 293 T cells as described (Lund et al., 2012) based on a btGMCSF plasmid (kindly provided by D. Werling, RVC, UK). The resulting activated monocytes were incubated with latex beads (FluoroSpheres 430/465, $20 \mu \mathrm{l}$ corresponding to $4 \times 10^{6}$ beads, 20 beads/cell, Life Technologies), pHrodo red E. coli or pHrodo red Zymosan (both from Life Technologies) in separate wells. Phagocytosis was terminated after $30 \mathrm{~min}$ of incubation $\left(37^{\circ} \mathrm{C}\right.$, $5 \% \mathrm{CO}_{2}$ ) by placing the plate on ice. The particle uptake was measured in a Gallios flow cytometer. The monocyte gate was adjusted to exclude free particles using cell-free particle-only samples as control.

To confirm that the particles had been phagocytized, monocytes were centrifuged onto slides at $1000 \mathrm{rpm}$ for $5 \mathrm{~min}$. The cells were fixed in acetone, blocked with goat serum and immunolabeled with mAb against human CD68 (Dako). The cytospots were incubated with secondary antibodies, Alexa 488 goat-anti-mouse IgG1 or Alexa 594 goat-anti-mouse IgG1, mounted in Prolong Gold Antifade reagent with DAPI (all from Life Technologies) and analyzed by standard fluorescence and confocal microscopy.

\section{Statistical Analysis}

All data was analyzed for statistical significance with the MannWhitney test and data reported with medians. A level of $P<0.05$ was considered statistically significant and shown as ${ }^{*}$ and $* *$ 
in figures. GraphPad prism version 6.04 software was used for statistical analyses.

\section{Results}

\section{Expression of $\mathrm{PrP}^{\mathrm{C}}$ in Leukocytes Correlates with Genotype}

The absence of $\mathrm{PrP}^{\mathrm{C}}$ on PBMCs from $P R N P^{\mathrm{Ter} / \mathrm{Ter}}$ goats was confirmed by three different anti- $\mathrm{PrP}^{\mathrm{C}} \mathrm{mAbs}$ (Figure $\mathbf{1 A}$ and data not shown). The fluorescence intensity of anti-PrP $\mathrm{P}^{\mathrm{C}}$-stained PBMCs showed that cells from $P R N P^{+/ T e r}$ goats expressed approximately half the density of surface $\mathrm{PrP}^{\mathrm{C}}$ as compared to those from $P R N P^{+/+}$goats. When co-staining for immune cell subpopulations, this pattern of $\mathrm{PrP}^{\mathrm{C}}$ expression was similar in monocytes $\left(\mathrm{CD} 14^{+}\right), \mathrm{B}$ cells $\left(\mathrm{B}-\mathrm{B} 2^{+}\right)$, and $\mathrm{T}$ cells $\left(\mathrm{CD}^{+}\right)$(data not shown). Anti-PrP $\mathrm{CAbs}$ staining of whole blood revealed that $\mathrm{PrP}^{\mathrm{C}}$ was not expressed on the surface of granulocytes in goats of either genotype, while its presence was confirmed in the lymphocyte gate in $P R N P^{+/+}$goats (Figure 1B).

To investigate whether reduced $\mathrm{PrP}^{\mathrm{C}}$ levels in $P R N P^{+/ \mathrm{Ter}}$ and $P R N P^{\text {Ter/Ter }}$ animals would lead to compensatory upregulation of PRNP mRNA, relative mRNA expression levels in PBMCs and bone marrow were analyzed. As shown in Figures 1C,D, the PRNP mRNA expression level in PBMCs from $P R N P^{\mathrm{Ter} / \mathrm{Ter}}$ animals was $16.8 \%$ of the expression in $P R N P^{+/+}$animals, whereas the expression level in $P R N P^{+/ T e r}$ PBMCs was $42.4 \%$ of the $P R N P^{+/+}$animals. In the bone marrow, the relative PRNP mRNA expression in the PRNP ${ }^{\text {Ter/Ter }}$ goat was $34 \%$ of the $P R N P^{+/+}$goat investigated (Figure 1D). Collectively, these data indicate that no compensatory mechanism is counteracting loss of $\mathrm{PrP}^{\mathrm{C}}$ at PRNP mRNA expression level and that $P R N P^{\mathrm{Ter} / \mathrm{Ter}}$ encoding mRNA is degraded.

A

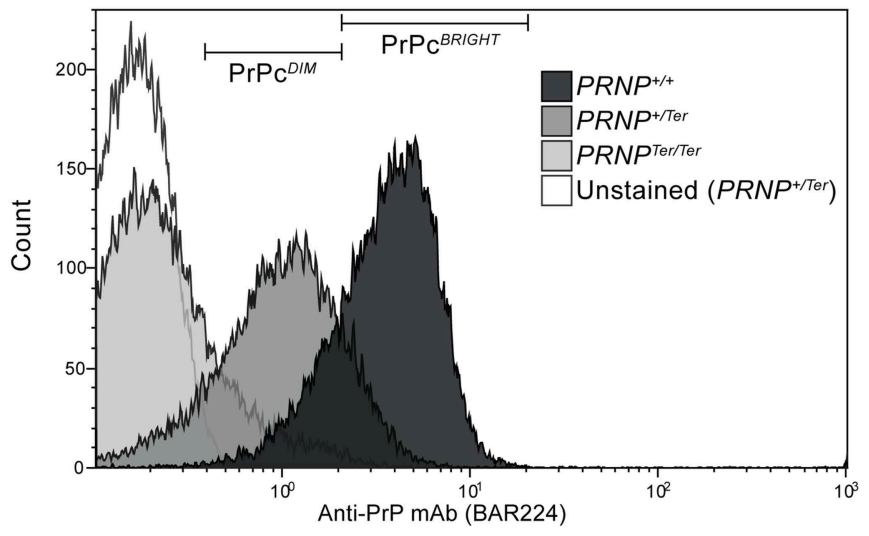

B
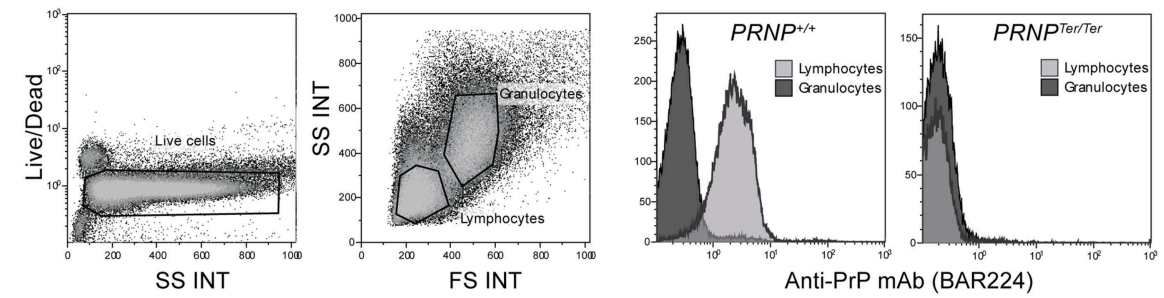

C

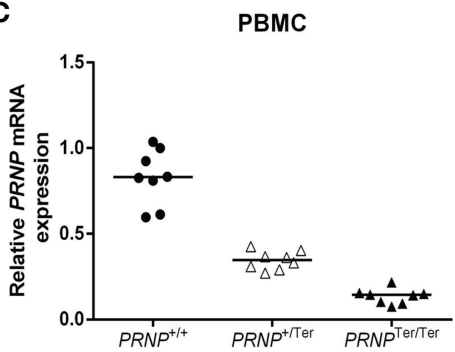

FIGURE 1 | (A-D) Relative PrPC expression and PRNP mRNA expression in PBMCs. (A) Representative plot of $\mathrm{PrPC}^{\mathrm{C}}$ expression on PBMCs is shown using anti-PrPC mAb BAR224. (B) Whole blood analysis showing gating of live cells into granulocyte and lymphocyte populations based on FS and SS characteristics. The two rightmost
D

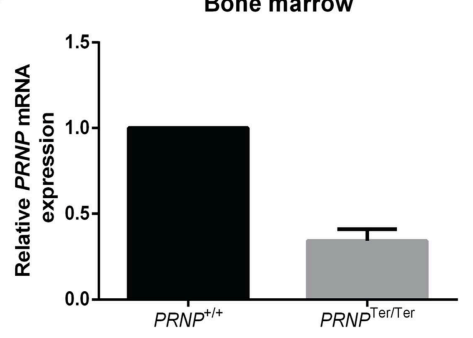

plots show representative PrPC expression on lymphocytes and granulocytes in PRNP $+/+(n=6)$ and PRNPTer/Ter $(n=2)$ animals. (C) Relative PRNP mRNA expression in PBMCs (each genotype $n=8$ ). (D) Relative PRNP mRNA expression in bone marrow (each genotype, $n=1$ ). 


\section{Red Blood Cell Numbers are Elevated in PRNP ${ }^{\text {Ter/Ter }}$ Animals}

To analyze whether reduced levels or complete lack of $\mathrm{PrP}^{\mathrm{C}}$ influences the cellular or chemical composition of the blood, we performed hematological and clinical chemistry analyses of $P R N P^{\text {Ter/Ter }}, P R N P^{+/ T e r}$ and $P R N P^{+/+}$goat kids between 3 and 4 weeks of age.

Clinical chemistry revealed a slightly, but significantly, lower magnesium level and an increased creatine level in $P R N P^{\mathrm{Ter}} / \mathrm{Ter}$ animals compared to $P R N P^{+/+}$, both well within the normal reference range (see Supplementary Table 2).

The number of RBCs was increased in $P R N P^{\text {Ter/Ter }}$ goat kids (Table 1 and Figure 2A) as compared to the $P R N P^{+/+}$ and $P R N P^{+/ T e r}$ groups. Mean cell volume of the RBCs (MCV) was not significantly different between the groups, although the distribution of values suggested a clear tendency of lower MCV in the $P R N P^{\text {Ter/Ter }}$ animals compared to the $P R N P^{+/+}$and $P R N P^{+/ T e r}$ groups (Table $\mathbf{1}$ and Figure 2B).

The groups did not differ in hematocrit (HCT) values (Table 1), suggesting that the reduced RBC volume was compensated by an increased number of RBCs or vice versa. To investigate if differences in iron uptake and metabolism could have any influence on RBC number and $\mathrm{MCV}$ we investigated the iron levels in blood serum. However, iron levels did not differ between the genotypes (Figure 2C).

TABLE 1 | Hematology results.

\begin{tabular}{|c|c|c|c|c|c|c|c|}
\hline & Reference range & \multicolumn{3}{|c|}{ Median } & \multicolumn{3}{|c|}{$P$-values } \\
\hline White blood cells $\left(\times 10^{9} / \mathrm{l}\right)$ & $4-16$ & 7.5 & 7.4 & 8.65 & 0.75 & 0.73 & 0.34 \\
\hline Red blood cells $\left(\times 10^{12} / \mathrm{l}\right)$ & $8-18$ & 10.61 & 10.58 & 11.78 & 0.8 & 0.006 & 0.007 \\
\hline Hemoglobin (g/l) & $75-125$ & 66 & 67 & 67 & 0.51 & 0.87 & 0.82 \\
\hline Hematocrit (I/I) & $0.22-0.38$ & 0.25 & 0.26 & 0.25 & 0.51 & 0.8 & 0.92 \\
\hline Mean corpuscular hemoglobin content (g/l) & $320-370$ & 267.5 & 262 & 270 & 0.51 & 0.11 & 0.058 \\
\hline $\operatorname{Rdw}(\%)$ & 23-35 & 53.8 & 53.1 & 52.2 & 0.99 & 0.62 & 0.76 \\
\hline Neutrophils $\left(\times 10^{9} / \mathrm{l}\right)$ & $1.5-8$ & 2.25 & 2.35 & 3.75 & 0.35 & 0.33 & 0.068 \\
\hline Lymphocytes (× 109//) & $2-9$ & 4.8 & 4.35 & 4.35 & 0.28 & 0.75 & 0.6 \\
\hline Monocytes (× 109/l) & $0-0.5$ & 0.35 & 0.45 & 0.45 & 0.028 & 0.91 & 0.08 \\
\hline
\end{tabular}

P-values $<0.05$ are shown in bold.

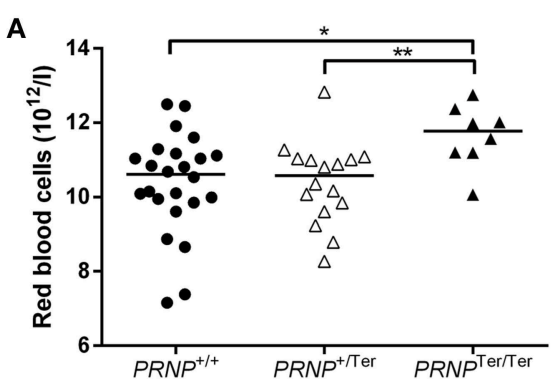

C

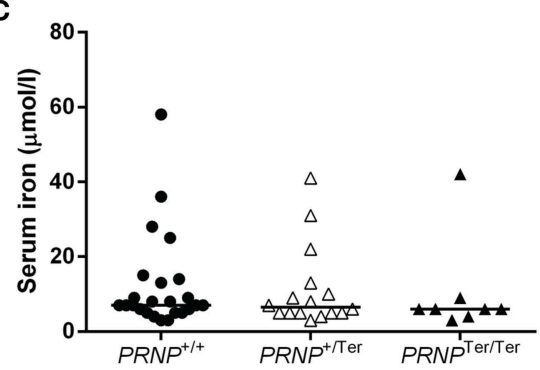

FIGURE 2 | Selected hematology parameters and serum iron values from 3 to 4 weeks old goat kids. Dot plots showing (A) the number of RBCs, (B) the RBC mean cell volume, (C) the serum
B

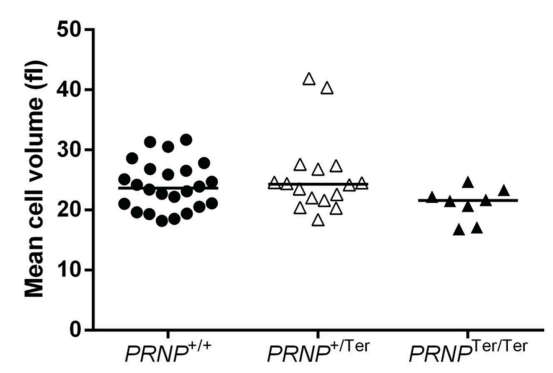

D

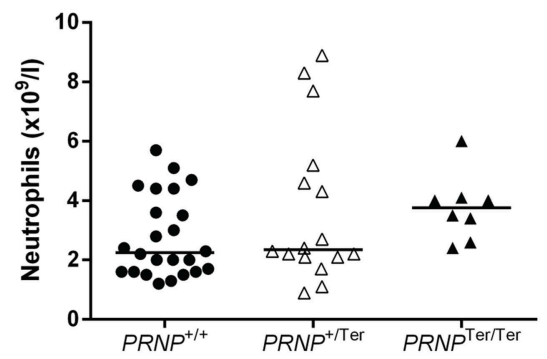

iron levels, and (D) absolute number of neutrophils in PRNPTer/Ter $(n=8)$, PRNP $P^{+/ T e r}(n=16)$, and PNRP $P^{+/+}(n=24)$ animals. * and ** indicate $P<0.05$. 
In blood smears from $P R N P^{\text {Ter/Ter }}(n=8)$ and $P R N P^{+/+}$ $(n=24)$ animals a marked poikilocytosis was observed, as expected in young kids. The neutrophil granulocytes were mature and showed no signs of left shift in any of the genotypes. No reticulocytes were present in any of the smears (data not shown).

Within the leukocyte populations, there was a tendency of a higher neutrophil count in the $P R N P^{\text {Ter/Ter }}$ animals as well as an increase in the monocyte number in $P R N P^{\mathrm{Ter} / \mathrm{Ter}}$ and $P R N P^{+/ T e r}$ animals compared to the $P R N P^{+/+}$group (Table 1 and Figure 2D). The majority of the hematology values were within the general reference ranges for goats, except mean cell hemoglobin content (MCHC), red cell distribution width (RDW), and hemoglobin, where values fell below the presented reference range in all genotypes. However, breedspecific reference ranges were not available, and since these low values were present in all groups they would most likely be within normal ranges for rapidly growing goat kids of this breed.

Observing that $\mathrm{PrP}^{\mathrm{C}}$ was highly expressed in a range of immune cells in normal goats we investigated whether lack of $\mathrm{PrP}^{\mathrm{C}}$ expression influenced the numbers of these cells in peripheral blood. The relative numbers of monocytes $\left(\mathrm{CD} 14^{+}\right), \mathrm{B}$ cells $\left(\mathrm{B}-\mathrm{B} 2^{+}\right)$, T cells $\left(\mathrm{CD} 3^{+}\right)$as well as the gamma-delta $\left(\mathrm{WC1}^{+}\right)$ and $\mathrm{CD}^{+}$subsets of $\mathrm{T}$ cells were quantified by flow cytometry (Figure 3). $\mathrm{CD} 4^{+}$T-cell labeling was excluded from the study due to methodological problems. No differences in numbers were revealed for any of these leukocyte subsets between the $P R N P^{+/+}$ and $P R N P^{\text {Ter/Ter }}$ genotypes.

\section{Morphological Analysis of Bone Marrow}

To investigate whether the observed difference in hematological profile could be reflected by morphological changes in bone marrow, smears, and imprints of bone marrow from 3 months old $P R N P^{+/+}(n=1)$ and $P R N P^{\text {Ter/Ter }}(n=1)$ goat kids were analyzed. However, there were no differences in myeloid/erythroid ratio between the two genotypes, and the precursor cells had a normal appearance. In addition, there was no observable difference in degree of apoptosis (data not shown). Altogether, no evident morphological changes
A

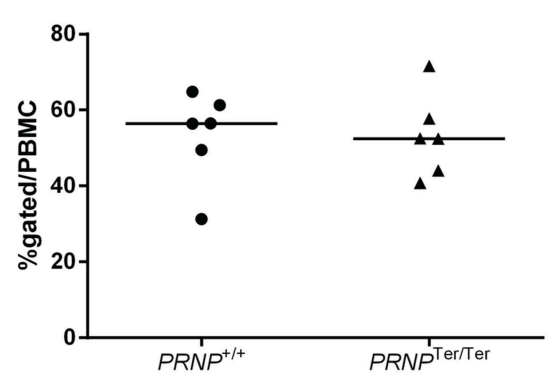

C

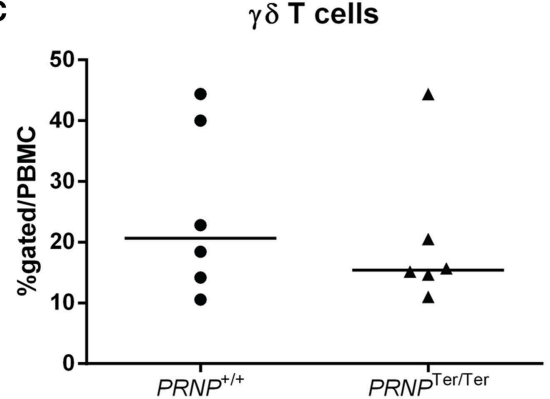

E

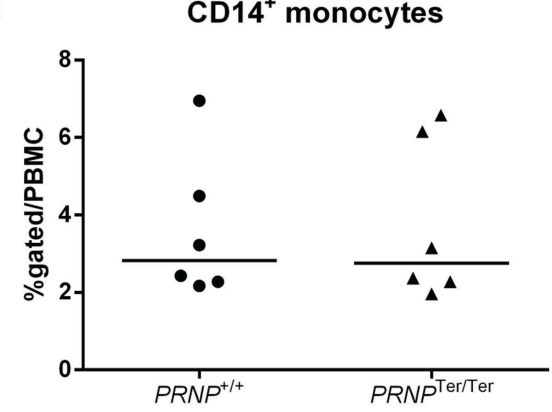

B

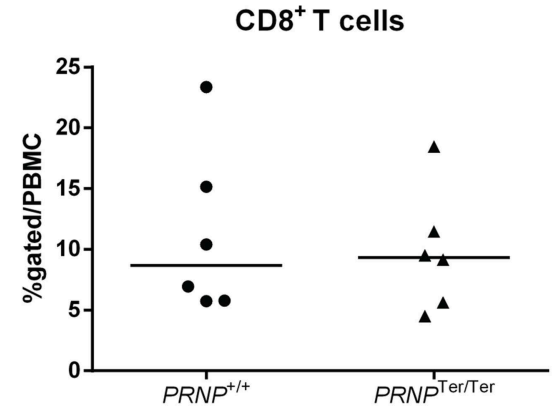

D

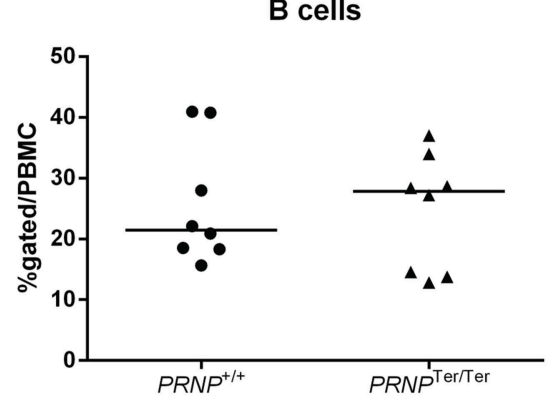

FIGURE 3 | Relative immune cell population sizes in 3-4 weeks old goat kids. Flow cytometric analysis of (A) CD3 ${ }^{+} \mathrm{T}$ cells, (B) $\mathrm{CD} 8^{+} \mathrm{T}$ cells, (C) $\gamma \delta \mathrm{T}$ cells, (D) B cells, and (E) $\mathrm{CD} 14^{+}$monocytes out of the total PBMC population. 
were found within the bone marrow of the $P R N P^{\text {Ter/Ter }}$ goat kid.

\section{Monocyte Phagocytosis and T-cell Proliferation Appear Unaltered in PRNP ${ }^{\mathrm{Ter}} / \mathrm{Ter}$ Animals}

To determine whether $\operatorname{PrP}^{\mathrm{C}}$ might have a functional impact on white blood cells, we performed phagocytosis and proliferation studies to assess two major functional properties of leukocytes. Positively selected CD14 ${ }^{+}$monocytes from peripheral blood were cultured for $24 \mathrm{~h}$ to stabilize cells following isolation, and supplemented with GM-CSF to activate the cells and prevent apoptosis (Bratton et al., 1995). The resulting shortterm activated monocytes were incubated with latex beads, bacteria (Escherichia coli), or zymosan-covered yeast cells (Saccharomyces cerevisiae) for $30 \mathrm{~min}$. Fluorescence and confocal microscopy of cytospots confirmed the cellular uptake of particles (Figures 4A-C and data not shown). A majority of the monocytes were $\mathrm{CD}^{+} 8^{+}$, consistent with monocytes or macrophages as previously described (Fadini et al., 2013). These cells had numerous vacuoles in the cytoplasm and a round to bean-shaped nucleus. All particle types were efficiently phagocytized by activated monocytes (Figures 4D,E). When comparing activated monocytes from $P R N P^{+/+}$and $P R N P^{\text {Ter/Ter }}$ goats by flow cytometry, we detected no significant differences between the genotypes in the proportions of cells that had taken up fluorescent particles, for none of the particle types (Figures 4 F-H). There was also no significant difference in the numbers of particles per cell measured as median fluorescent intensity of positive cells; or in the case of latex beads, the number of cells that had engulfed 2 beads or more (Figure 4E and data not shown).

To investigate if $\mathrm{PrP}^{\mathrm{C}}$ expression could be involved in cellular proliferation, we stimulated PBMCs in vitro using the mitogen Con A or the cytokines IL-2 or IL-15 to cover proliferation of $\mathrm{T}$ cells and NK cells/innate lymphocytes (Figure 5). The cell cultures proliferated well in response to these stimuli, but no significant differences between the groups were observed, although a slightly higher median response of cells from the PRNP $P^{\text {Ter/Ter }}$ group was noted for all stimulations.

Collectively, these results suggest that loss of $\operatorname{PrP}^{\mathrm{C}}$ does not have any major influence on the phagocytic ability of activated monocytes or the proliferative capacity of T or NK cells in vitro.

\section{Discussion}

The $\mathrm{PrP}^{\mathrm{C}}$ is phylogenetically conserved and widely present in vertebrates (Harrison et al., 2010), pointing to an essential role for the organism. Non-transgenic animals naturally devoid of $\mathrm{PrP}^{\mathrm{C}}$, which has not been reported until recently (Benestad et al., 2012), could provide essential information regarding $\operatorname{PrP}^{C}$ physiology and function. In the present study we have observed that such $P R N P^{\mathrm{Ter} / \mathrm{Ter}}$ goats present with hematological changes, although without morphological changes in the bone marrow or alterations in major immune parameters.

By investigating complete blood counts of 3-4 weeks old goat kids we demonstrated that $P R N P^{\text {Ter/Ter }}$ animals had a significantly higher number of RBC compared to matched $P R N P^{+/+}$controls. Tendencies of changes in other hematological values were also observed, such as lowered MCV and increased amounts of neutrophil granulocytes. These results are strikingly similar to the hematological observations in 10 months old $\mathrm{PrP}^{\mathrm{C}} \mathrm{KO}$ cattle (Richt et al., 2007), which had increased numbers of RBC, WBC, and neutrophil granulocytes, and lowered MCV and MCH. The authors of the study questioned if the gene cassette used in the transgenic procedure rather than the absence of $\operatorname{PrP}^{\mathrm{C}}$ per se could have caused the observed differences. Our findings in naturally mutated animals strengthen the likelihood that $\mathrm{PrP}^{\mathrm{C}}$ loss may physiologically affect RBC parameters and neutrophil numbers in young ruminants. Preliminary hematology results from adult goats have revealed no differences between the genotypes in any of the hematological values (unpublished results).

Several experimental approaches have shown that phenotypes related to loss of $\mathrm{PrP}^{\mathrm{C}}$ are only clearly evident under various stressful conditions, such as tissue damage, infection, or anemia (Zivny et al., 2008; Gourdain et al., 2012). Likewise, it could be speculated that the increased demand for cell proliferation in the bone marrow during growth represents a physiological stress which reveals an otherwise cryptic phenotype caused by loss of $\mathrm{PrP}^{\mathrm{C}}$. Accordingly; a relatively subtle impact would not be observable in adult goats with lower bone marrow activity.

Mice lacking $\operatorname{PrP}^{\mathrm{C}}$ have been reported to be in a chronic state of systemic iron deficiency, ascribed to inefficient uptake and transport into the blood stream, as well as inefficient uptake in various recipient cells, which could be rescued by the reintroduction of $\mathrm{PrP}^{\mathrm{C}}$ (Singh et al., 2009). To rule out any impact of iron deficiency on the erythroid lineage we analyzed iron levels in all investigated animals. Although a smaller cell volume could be a result of an iron deficiency, we did not detect any difference in circulating iron levels that would support a state of systemic iron deficiency in PRNP $P^{\text {Ter/Ter }}$ animals.

Studies in $\mathrm{PrP}^{\mathrm{C}} \mathrm{KO}$ mice have suggested a possible influence of $\mathrm{PrP}^{\mathrm{C}}$ on long-term hematopoietic stem cells (LT-HSCs), as these cells showed reduced regenerative capacity when undergoing serial transplantations (Zhang et al., 2006). However, before the interventions, mice were normal with respect to blood cell levels and presence of cell lineage profiles in the bone marrow. In the present study, we did not observe morphological evidence of bone marrow impairment, as apoptosis rate and myeloid/erythroid ratio was found similar in a $P R N P^{\text {Ter/Ter }}$ animal compared to a normal control. More comprehensive and cell-specific investigations are however needed to clarify whether there are changes in bone marrow cellular composition in growing $P R N P^{\mathrm{Ter} / \mathrm{Ter}}$ kids, and further studies are needed to reach a final conclusion regarding possible differences between genotypes with respect to stem cell phenotypes in animals, both under normal and stressful conditions.

We detected high $\mathrm{PrP}^{\mathrm{C}}$ expression in peripheral blood mononuclear leukocytes but not granulocytes of $P R N P^{+/+}$ animals, similar to previous reports that have led to a particular interest for $\mathrm{PrP}^{\mathrm{C}}$ functions in immune cells, several of which have suggested $\mathrm{PrP}^{\mathrm{C}}$ involvement in immune cell functions (Dodelet and Cashman, 1998; Barclay et al., 1999; Durig et al., 2000; Holada and Vostal, 2000; Herrmann et al., 2001; Halliday 

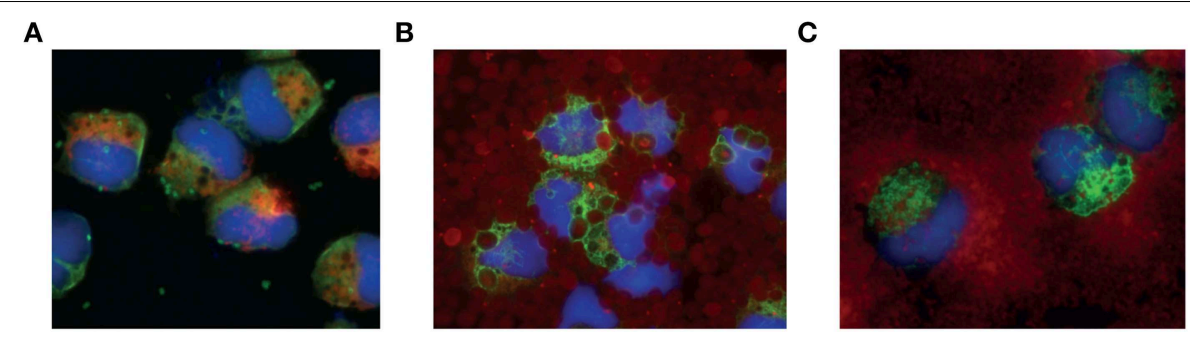

D

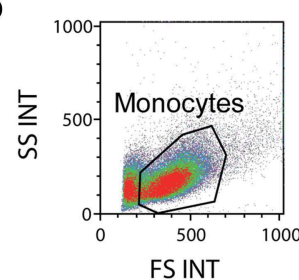

$\mathbf{F}$

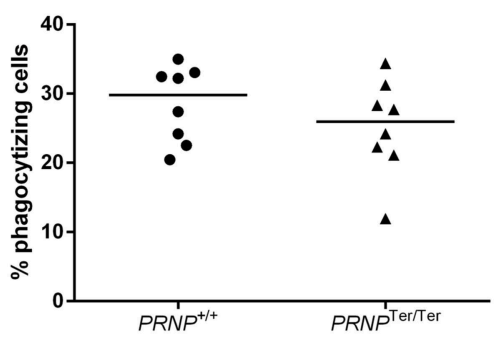

H

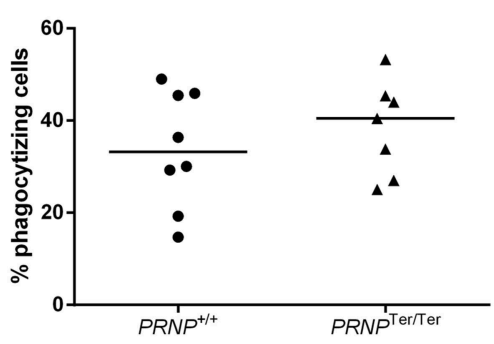

FIGURE 4 | Phagocytosis assays. Cytospots confirmed the cellular uptake of (A) latex beads (green fluorescence), (B) E. coli (red fluorescence), and (C) Zymosan (red fluorescence) in activated monocytes. Additional staining for nuclei (blue) and CD68 (A red, B and C green). (D) Gating of live cells based on FS and SS characteristics in flow cytometry. (E) Particle uptake in $P R N P^{T e r} /$ Ter and $P R N P^{+/+}$cells based on the results from two
E

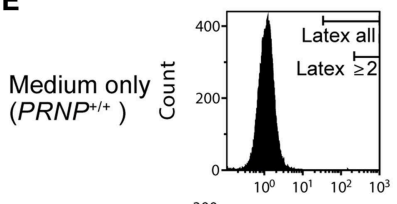

PRNP $+1+$
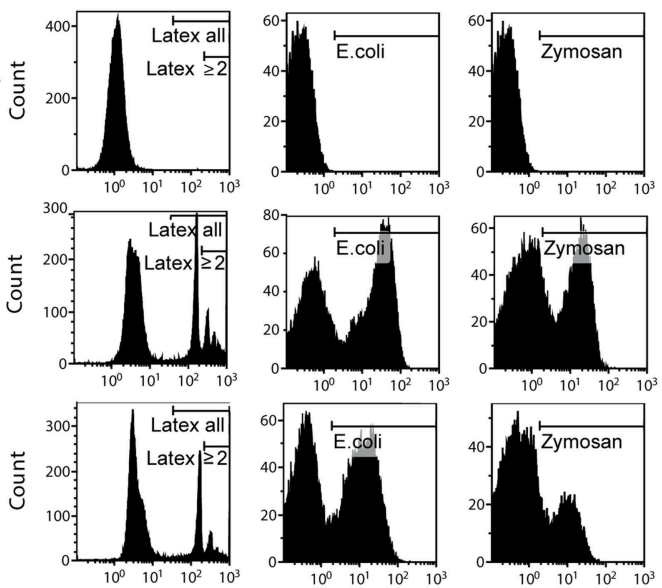

FL9 INT

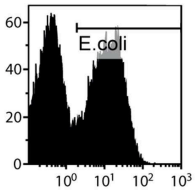

FL2 INT

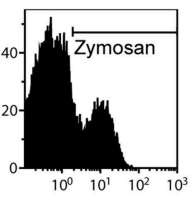

Zymosan

G

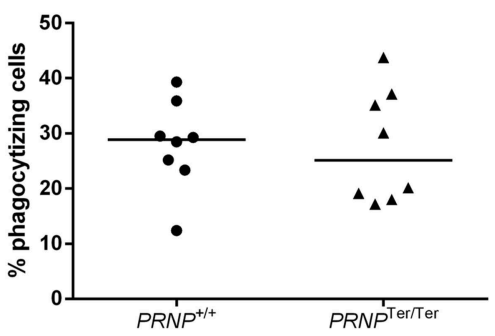

representative animals. Medium only was used as control. Gates indicate particle-containing cells, and in the case of latex beads, also gates for cells that had engulfed 2 particles or more (F-H) Compiled results of all animals showing percentage of monocytes containing (F) latex beads, (G) Zymosan and $\mathbf{( H )}$ E. coli, as measured by flow cytometry. For each assay, $n=8$, except $P R N P^{\text {Ter }} /$ Ter $E$. coli where $n=7$.

et al., 2005; Dassanayake et al., 2012). Hematological analysis suggested a higher count of neutrophil granulocytes and possibly monocytes in $P R N P^{\text {Ter/Ter }}$ kids, while flow cytometric analyses did not confirm any difference in $\mathrm{CD}_{1}{ }^{+}$monocyte numbers, and relative numbers of other major circulating mononuclear cell subsets also appeared unaffected by $\mathrm{PrP}^{\mathrm{C}}$ loss. Similar results, 

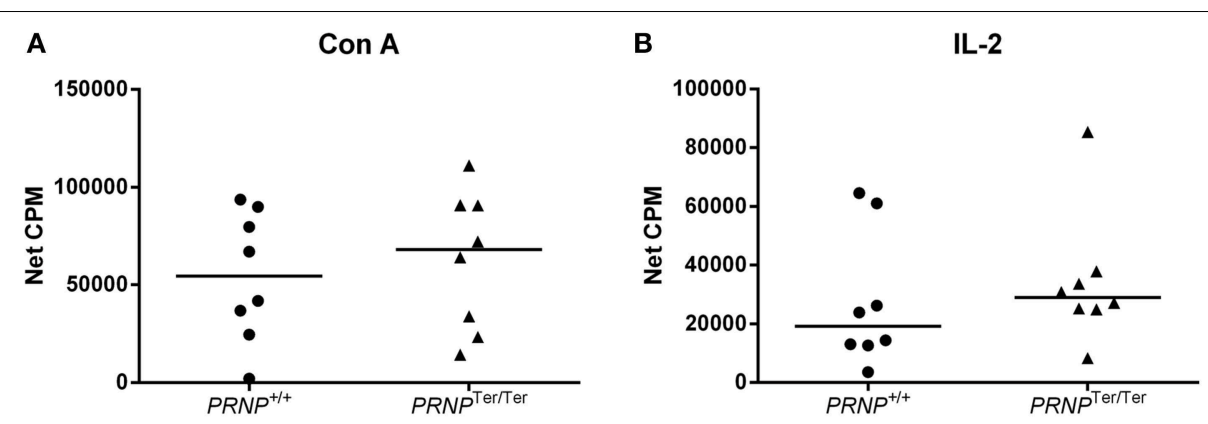

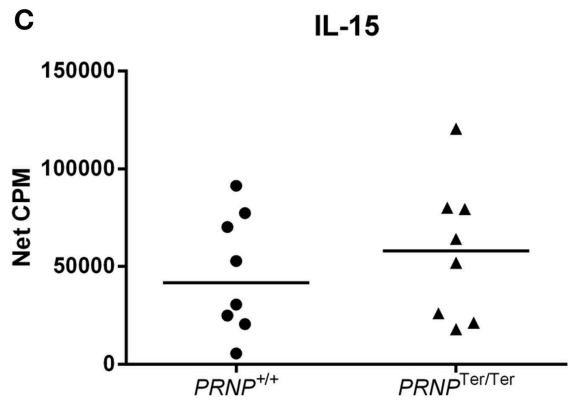

FIGURE 5 | Lymphocyte proliferation test. Proliferation of T cells after $72 \mathrm{~h}$ stimulation with (A) Con A, (B) IL-2, and (C) IL-15, measured as beta emission following DNA incorporation of tritiated thymidine (net CPM $=$ sample CPM - control CPM). In all cases $n=8$.

including increased neutrophil counts, have been found in $\mathrm{KO}$ cattle, although a tendency of more numerous $\gamma \delta \mathrm{T}$ cells in a group of four $\mathrm{PrP}^{\mathrm{C}}$ cattle compared to four WT cattle, was found (Richt et al., 2007). Few similar studies have been done in murine $\mathrm{PrP}^{\mathrm{C}} \mathrm{KO}$ models but in a double $\mathrm{KO}$, namely $\mathrm{PrP}^{\mathrm{C}}$ and Doppel $\mathrm{KO}$ mice, no alterations in the immune cell populations were noted (Genoud et al., 2004). Seen together these results indicate that mechanisms that regulate the levels of immune cells in the blood are largely independent of $\operatorname{PrP}^{\mathrm{C}}$.

It has been shown that $\operatorname{PrP}^{C}$ is expressed in regulatory and memory $\mathrm{T}$ cells (Li et al., 2001), and that levels of $\mathrm{PrPC}^{\mathrm{C}}$ increase during T-cell proliferation (Cashman et al., 1990; Mabbott et al., 1997). Furthermore, T cells lacking $\operatorname{PrP}^{\mathrm{C}}$ display reduced proliferation rates (Mabbott et al., 1997). Here, we stimulated PBMCs in vitro with mitogen or cytokines to assess alternative proliferation pathways but detected no difference in the proliferation rates between the genotypes. This correlates with the findings in transgenic cattle (Richt et al., 2007). Nevertheless, a slightly higher mean response in the $P R N P^{\text {Ter/Ter }}$ group consistent through all stimulations could suggest that proliferative differences may be present in more restricted lymphocyte subsets. Furthermore, we quantified the uptake of bacteria, yeast and latex particles by activated blood monocytes in order to approach different activation pathways of phagocytosis (Flannagan et al., 2012). We did not find that $\operatorname{PrP}^{\mathrm{C}}$ deficiency had any influence on the proportion or efficiency of monocytes to phagocytize any of these particle types. Earlier studies on phagocytosis have been performed with cells from $\mathrm{PrP}^{\mathrm{C}} \mathrm{KO}$ mice and have given conflicting results. In an in vitro study of phagocytosis of E. coli by bone marrow-derived macrophages, the activity was enhanced in cells from $\mathrm{PrP}^{\mathrm{C}} \mathrm{KO}$ mice (Wang et al., 2014). Conversely, macrophages from $\operatorname{PrP}^{\mathrm{C}} \mathrm{KO}$ mice were shown to phagocytize latex beads at a lower rate than macrophages from WT mice (Uraki et al., 2010). In another study, De Almeida et al. (2005) found that $\mathrm{PrP}^{\mathrm{C}}$ is a negative modulator of phagocytosis, as peritoneal macrophages from $\mathrm{PrP}^{\mathrm{C}} \mathrm{KO}$ mice phagocytized apoptotic cells at a higher rate than cells from WT mice in vitro and in vivo, a result confirmed by two different mouse strains. The results from the latter study have later been linked to polymorphisms in $\mathrm{PrP}^{\mathrm{C}}$ flanking genes involved in phagocytosis, rather than the loss of $\operatorname{PrP}^{\mathrm{C}}$ in itself (Nuvolone et al., 2013), and similar concerns might be raised regarding other reports on $\mathrm{PrP}^{\mathrm{C}}$ functions from $\mathrm{PrP}^{\mathrm{C}} \mathrm{KO}$ models. Our results from naturally $\mathrm{PrP}^{\mathrm{C}}$-devoid animals are not in support of a principal mechanistic role of the prion protein neither in lymphocyte proliferation nor in phagocytosis.

In summary, this study showed that naturally occurring $\operatorname{PrP}^{\mathrm{C}}$. deficient goat kids displayed a generally healthy constitution, moderate shifts in red blood cell and possibly granulocytic cell lineages but not in other major circulating hematopoietic cells. No impairment of major immune cell functions was detected. These results point toward a role for $\operatorname{PrP}^{\mathrm{C}}$ related to maturation and release of selected cell lineages from the bone marrow, and underscore previous observations that $\mathrm{PrP}^{\mathrm{C}}$ loss appears to have limited physiological or pathological consequences for the animal, at least under conventional living conditions and in the absence of significant stressors. The present natural goat model offers a unique opportunity to study the function of $\mathrm{PrP}^{\mathrm{C}}$ in and ex vivo without the confounding factors of genetic engineering, which may hopefully help to 
shed light on the elusive nature of this protein and its related diseases.

\section{Author Contributions}

$\mathrm{PB}, \mathrm{AE}, \mathrm{MT}, \mathrm{MB}, \mathrm{MR}$ designed the study. $\mathrm{MR}, \mathrm{PB}, \mathrm{MB}$ performed the experiments and MR, $\mathrm{PB}, \mathrm{MT}, \mathrm{AE}, \mathrm{MB}$ analyzed the data. AL assisted with the monocyte isolation protocol and experiments and $\mathrm{HB}$ contributed to the analysis of hematology data, blood smears and bone marrow imprints, and smears. $M R, M B$, $\mathrm{HB}, \mathrm{AL}, \mathrm{IO}, \mathrm{MT}, \mathrm{AE}, \mathrm{PB}$ wrote or critically reviewed the manuscript.

\section{References}

Bainbridge, J., and Walker, K. B. (2005). The normal cellular form of prion protein modulates $\mathrm{T}$ cell responses. Immunol. Lett. 96, 147-150. doi: 10.1016/j.imlet.2004.08.006

Barclay, G. R., Hope, J., Birkett, C. R., and Turner, M. L. (1999). Distribution of cellassociated prion protein in normal adult blood determined by flow cytometry. Br. J. Haematol. 107, 804-814. doi: 10.1046/j.1365-2141.1999.01789.x

Bendheim, P. E., Brown, H. R., Rudelli, R. D., Scala, L. J., Goller, N. L., Wen, G. Y., et al. (1992). Nearly ubiquitous tissue distribution of the scrapie agent precursor protein. Neurology 42, 149-156. doi: 10.1212/WNL.42.1.149

Benestad, S. L., Austbo, L., Tranulis, M. A., Espenes, A., and Olsaker, I. (2012). Healthy goats naturally devoid of prion protein. Vet. Res. 43:87. doi: 10.1186/1297-9716-43-87

Brandner, S., Isenmann, S., Raeber, A., Fischer, M., Sailer, A., Kobayashi, Y., et al. (1996a). Normal host prion protein necessary for scrapie-induced neurotoxicity. Nature 379, 339-343. doi: 10.1038/379339a0

Brandner, S., Raeber, A., Sailer, A., Blattler, T., Fischer, M., Weissmann, C., et al. (1996b). Normal host prion protein (PrPC) is required for scrapie spread within the central nervous system. Proc. Natl. Acad. Sci. U.S.A. 93, 13148-13151. doi: 10.1073/pnas.93.23.13148

Bratton, D. L., Hamid, Q., Boguniewicz, M., Doherty, D. E., Kailey, J. M., and Leung, D. Y. (1995). Granulocyte macrophage colony-stimulating factor contributes to enhanced monocyte survival in chronic atopic dermatitis. J. Clin. Invest. 95, 211-218. doi: 10.1172/JCI117642

Bueler, H., Fischer, M., Lang, Y., Bluethmann, H., Lipp, H. P., Dearmond, S. J., et al. (1992). Normal development and behaviour of mice lacking the neuronal cell-surface PrP protein. Nature 356, 577-582. doi: 10.1038/356577a0

Cashman, N. R., Loertscher, R., Nalbantoglu, J., Shaw, I., Kascsak, R. J., Bolton, D. C., et al. (1990). Cellular isoform of the scrapie agent protein participates in lymphocyte activation. Cell 61, 185-192. doi: 10.1016/0092-8674(90)90225-4

Connelley, T., Storset, A. K., Pemberton, A., Machugh, N., Brown, J., Lund, H., et al. (2011). NKp46 defines ovine cells that have characteristics corresponding to NK cells. Vet. Res. 42:37. doi: 10.1186/1297-9716-42-37

Dassanayake, R. P., Schneider, D. A., Herrmann-Hoesing, L. M., Truscott, T. C., Davis, W. C., et al. (2012). Cell-surface expression of PrPC and the presence of scrapie prions in the blood of goats. J. Gen. Virol. 93, 1127-1131. doi: 10.1099/vir.0.039032-0

De Almeida, C. J., Chiarini, L. B., Da Silva, J. P., Pm, E. S., Martins, M. A., and Linden, R. (2005). The cellular prion protein modulates phagocytosis and inflammatory response. J. Leukoc. Biol. 77, 238-246. doi: 10.1189/jlb.1103531

Dodelet, V. C., and Cashman, N. R. (1998). Prion protein expression in human leukocyte differentiation. Blood 91, 1556-1561.

Durig, J., Giese, A., Schulz-Schaeffer, W., Rosenthal, C., Schmucker, U., Bieschke, J., et al. (2000). Differential constitutive and activation-dependent expression of prion protein in human peripheral blood leucocytes. Br. J. Haematol. 108, 488-495. doi: 10.1046/j.1365-2141.2000.01881.x

Fadini, G. P., Cappellari, R., Mazzucato, M., Agostini, C., Vigili de Kreutzenberg, S., and Avogaro, A. (2013). Monocyte-macrophage polarization balance in pre-diabetic individuals. Acta Diabetol. 50, 977-982. doi: 10.1007/s00592-01 3-0517-3

\section{Acknowledgments}

We thank Anne K. Storset for methodological advice and Grethe M. Johansen, Tone Laila Aune, and Susan Skogtvedt Røed for technical help. The work was supported by The Research Council of Norway, grant 227386/E40.

\section{Supplementary Material}

The Supplementary Material for this article can be found online at: http://journal.frontiersin.org/article/10.3389/fcell. 2015.00044

Flannagan, R. S., Jaumouille, V., and Grinstein, S. (2012). The cell biology of phagocytosis. Annu. Rev. Pathol. 7, 61-98. doi: 10.1146/annurev-pathol011811-132445

Ford, M. J., Burton, L. J., Morris, R. J., and Hall, S. M. (2002). Selective expression of prion protein in peripheral tissues of the adult mouse. Neuroscience 113, 177-192. doi: 10.1016/S0306-4522(02)00155-0

Genoud, N., Behrens, A., Miele, G., Robay, D., Heppner, F. L., Freigang, S., et al. (2004). Disruption of Doppel prevents neurodegeneration in mice with extensive Prnp deletions. Proc. Natl. Acad. Sci. U.S.A. 101, 4198-4203. doi: 10.1073/pnas.0400131101

Gourdain, P., Ballerini, C., Nicot, A. B., and Carnaud, C. (2012). Exacerbation of experimental autoimmune encephalomyelitis in prion protein $(\mathrm{PrPc})$ null mice: evidence for a critical role of the central nervous system. J. Neuroinflammation 9:25. doi: 10.1186/1742-2094-9-25

Halliday, S., Houston, F., and Hunter, N. (2005). Expression of PrPC on cellular components of sheep blood. J. Gen. Virol. 86, 1571-1579. doi: 10.1099/vir.0.80561-0

Harrison, P. M., Khachane, A., and Kumar, M. (2010). Genomic assessment of the evolution of the prion protein gene family in vertebrates. Genomics 95, 268-277. doi: 10.1016/j.ygeno.2010.02.008

Herrmann, L. M., Davis, W. C., Knowles, D. P., Wardrop, K. J., Sy, M. S., Gambetti, P., et al. (2001). Cellular prion protein is expressed on peripheral blood mononuclear cells but not platelets of normal and scrapie-infected sheep. Haematologica 86, 146-153.

Holada, K., and Vostal, J. G. (2000). Different levels of prion protein (PrPc) expression on hamster, mouse and human blood cells. Br. J. Haematol. 110, 472-480. doi: 10.1046/j.1365-2141.2000.02158.x

Horiuchi, M., Yamazaki, N., Ikeda, T., Ishiguro, N., and Shinagawa, M. (1995). A cellular form of prion protein (PrPC) exists in many non-neuronal tissues of sheep. J. Gen. Virol. 76(Pt 10), 2583-2587. doi: 10.1099/0022-1317-76-1 $0-2583$

Isaacs, J. D., Jackson, G. S., and Altmann, D. M. (2006). The role of the cellular prion protein in the immune system. Clin. Exp. Immunol. 146, 1-8. doi: 10.1111/j.1365-2249.2006.03194.x

Khosravani, H., Zhang, Y., Tsutsui, S., Hameed, S., Altier, C., Hamid, J., et al. (2008). Prion protein attenuates excitotoxicity by inhibiting NMDA receptors. J. Gen. Physiol. 131, i5. doi: 10.1085/JGP1316OIA5

Krebs, B., Dorner-Ciossek, C., Schmalzbauer, R., Vassallo, N., Herms, J., and Kretzschmar, H. A. (2006). Prion protein induced signaling cascades in monocytes. Biochem. Biophys. Res. Commun. 340, 13-22. doi: 10.1016/j.bbrc.2005.11.158

Kretzschmar, H. A., Prusiner, S. B., Stowring, L. E., and Dearmond, S. J. (1986). Scrapie prion proteins are synthesized in neurons. Am. J. Pathol. 122, 1-5.

Li, R., Liu, D., Zanusso, G., Liu, T., Fayen, J. D., Huang, J. H., et al. (2001). The expression and potential function of cellular prion protein in human lymphocytes. Cell. Immunol. 207, 49-58. doi: 10.1006/cimm.20 00.1751

Lund, H., Boysen, P., Dean, G. A., Davis, W. C., Park, K. T., and Storset, A. K. (2012). Interleukin-15 activated bovine natural killer cells express CD69 and produce interferon-gamma. Vet. Immunol. Immunopathol. 150, 79-89. doi: 10.1016/j.vetimm.2012.08.011 
Mabbott, N. A., Brown, K. L., Manson, J., and Bruce, M. E. (1997). T-lymphocyte activation and the cellular form of the prion protein. Immunology 92, 161-165. doi: 10.1046/j.1365-2567.1997.00331.x

Manson, J. C., Clarke, A. R., Hooper, M. L., Aitchison, L., Mcconnell, I., and Hope, J. (1994). 129/Ola mice carrying a null mutation in PrP that abolishes mRNA production are developmentally normal. Mol. Neurobiol. 8, 121-127. doi: $10.1007 / \mathrm{BF} 02780662$

Mariante, R. M., Nobrega, A., Martins, R. A., Areal, R. B., Bellio, M., and Linden, R. (2012). Neuroimmunoendocrine regulation of the prion protein in neutrophils. J. Biol. Chem. 287, 35506-35515. doi: 10.1074/jbc.M112.394924

Massimino, M. L., Redaelli, M., Bertoli, A., Sorgato, M. C., and MucignatCaretta, C. (2013). Altered behavioral aspects of aged mice lacking the cellular prion protein. Physiol. Behav. 119, 86-91. doi: 10.1016/j.physbeh.2013. 06.006

Mattei, V., Garofalo, T., Misasi, R., Circella, A., Manganelli, V., Lucania, G., et al. (2004). Prion protein is a component of the multimolecular signaling complex involved in T cell activation. FEBS Lett. 560, 14-18. doi: 10.1016/S00145793(04)00029-8

Miranda, A., Pericuesta, E., Ramirez, M. A., and Gutierrez-Adan, A. (2011). Prion protein in ESC regulation. Prion 5, 169-171. doi: 10.4161/pri.5. 3.16797

Nagel-Alne, G. E., Asheim, L. J., Hardaker, J. B., Solverod, L., Lindheim, D., and Valle, P. S. (2014). The Norwegian Healthier Goats programmea financial cost-benefit analysis. Prev. Vet. Med. 114, 96-105. doi: 10.1016/j.prevetmed.2014.02.002

Nuvolone, M., Kana, V., Hutter, G., Sakata, D., Mortin-Toth, S. M., Russo, G., et al. (2013). SIRPalpha polymorphisms, but not the prion protein, control phagocytosis of apoptotic cells. J. Exp. Med. 210, 2539-2552. doi: 10.1084/jem.20131274

Olsen, L., Boysen, P., Akesson, C. P., Gunnes, G., Connelley, T., Storset, A. K., et al. (2013). Characterization of NCR1+ cells residing in lymphoid tissues in the gut of lambs indicates that the majority are NK cells. Vet. Res. 44:109. doi: 10.1186/1297-9716-44-109

Prusiner, S. B. (1982). Novel proteinaceous infectious particles cause scrapie. Science 216, 136-144. doi: 10.1126/science.6801762

Prusiner, S. B., Scott, M. R., Dearmond, S. J., and Cohen, F. E. (1998). Prion protein biology. Cell 93, 337-348. doi: 10.1016/S0092-8674(00)81163-0

Richt, J. A., Kasinathan, P., Hamir, A. N., Castilla, J., Sathiyaseelan, T., Vargas, F., et al. (2007). Production of cattle lacking prion protein. Nat. Biotechnol. 25, 132-138. doi: 10.1038/nbt1271

Roesler, R., Walz, R., Quevedo, J., De-Paris, F., Zanata, S. M., Graner, E., et al. (1999). Normal inhibitory avoidance learning and anxiety, but increased locomotor activity in mice devoid of $\operatorname{PrP}(\mathrm{C})$. Brain Res. Mol. Brain Res. 71, 349-353. doi: 10.1016/S0169-328X(99)00193-X
Singh, A., Kong, Q., Luo, X., Petersen, R. B., Meyerson, H., and Singh, N. (2009). Prion protein (PrP) knock-out mice show altered iron metabolism: a functional role for PrP in iron uptake and transport. PLoS ONE 4:e6115. doi: 10.1371/journal.pone.0006115

Steele, A. D., Lindquist, S., and Aguzzi, A. (2007). The prion protein knockout mouse: a phenotype under challenge. Prion 1,83-93. doi: 10.4161/pri.1.2.4346

Storset, A. K., Hasvold, H. J., Valheim, M., Brun-Hansen, H., Berntsen, G., Whist, S. K., et al. (2001). Subclinical paratuberculosis in goats following experimental infection. An immunological and microbiological study. Vet. Immunol. Immunopathol. 80, 271-287. doi: 10.1016/S0165-2427(01)00294-X

Tobler, I., Gaus, S. E., Deboer, T., Achermann, P., Fischer, M., Rulicke, T., et al. (1996). Altered circadian activity rhythms and sleep in mice devoid of prion protein. Nature 380, 639-642. doi: 10.1038/380639a0

Uraki, R., Sakudo, A., Ando, S., Kitani, H., and Onodera, T. (2010). Enhancement of phagocytotic activity by prion protein in PrP-deficient macrophage cells. Int. J. Mol. Med. 26, 527-532. doi: 10.3892/ijmm_00000495

Wang, M., Zhao, D., Yang, Y., Liu, J., Wang, J., Yin, X., et al. (2014). The cellular prion protein negatively regulates phagocytosis and cytokine expression in murine bone marrow-derived macrophages. PLoS ONE 9:e102785. doi: 10.1371/journal.pone.0102785

Wong, B. S., Brown, D. R., Pan, T., Whiteman, M., Liu, T., Bu, X., et al. (2001). Oxidative impairment in scrapie-infected mice is associated with brain metals perturbations and altered antioxidant activities. J. Neurochem. 79, 689-698. doi: 10.1046/j.1471-4159.2001.00625.x

Zhang, C. C., Steele, A. D., Lindquist, S., and Lodish, H. F. (2006). Prion protein is expressed on long-term repopulating hematopoietic stem cells and is important for their self-renewal. Proc. Natl. Acad. Sci. U.S.A. 103, 2184-2189. doi: 10.1073/pnas.0510577103

Zivny, J. H., Gelderman, M. P., Xu, F., Piper, J., Holada, K., Simak, J., et al. (2008). Reduced erythroid cell and erythropoietin production in response to acute anemia in prion protein-deficient (Prnp-/-) mice. Blood Cells Mol. Dis. 40, 302-307. doi: 10.1016/j.bcmd.2007.09.009

Conflict of Interest Statement: The authors declare that the research was conducted in the absence of any commercial or financial relationships that could be construed as a potential conflict of interest.

Copyright (c) 2015 Reiten, Bakkebø, Brun-Hansen, Lewandowska-Sabat, Olsaker, Tranulis, Espenes and Boysen. This is an open-access article distributed under the terms of the Creative Commons Attribution License (CC BY). The use, distribution or reproduction in other forums is permitted, provided the original author(s) or licensor are credited and that the original publication in this journal is cited, in accordance with accepted academic practice. No use, distribution or reproduction is permitted which does not comply with these terms. 